\title{
Interruption of anticoagulation in patients undergoing elective surgical procedures
}

\section{Przerywanie terapii przeciwzakrzepowej u pacjentów poddawanych planowym zabiegom chirurgicznym}

\author{
Agnieszka Łętek ${ }^{1,2}$, Łukasz Zandecki,2, Agnieszka Janion-Sadowskaํ․ Anna Polewczyk ${ }^{1,2}$ \\ ${ }^{1}$ I Clinic of Cardiology, Regional Polyclinical Hospital, Kielce Region Centre of Cardiology, Kielce, Poland \\ Head of Clinic: Prof. Marianna Janion MD, PhD \\ 2Department of Physiology, Pathophysiology and Clinical Immunology, Collegium Medicum, Jan Kochanowski University, Kielce, Poland \\ Head of Collegium: Prof. Marianna Janion MD, PhD
}

Key words: oral anticoagulants, surgical procedures, thromboembolic risk, risk of bleeding.

Słowa kluczowe: doustne antykoagulanty, operacje chirurgiczne, ryzyko zakrzepowo-zatorowe, ryzyko krwawienia.

\begin{abstract}
Interruption of long-term therapy with oral anticoagulants in patients undergoing elective surgical procedures is a common problem in clinical practice. A large number of patients are receiving oral anticoagulants due to atrial fibrillation, mechanical prosthetic valves, or thromboembolic disease. Each year many of these patients will undergo an invasive procedure. The most important aspect is the risk-benefit assessment: the general risk of bleeding related to the procedure, additional risk of bleeding during the procedure related to anticoagulants, and on the other hand the risk of thrombotic complications such as ischaemic stroke or coronary stent thrombosis, associated with discontinuation of the antithrombotic therapy. The aim of the article is to present the management of anticoagulant therapy in patients undergoing elective surgical procedures.
\end{abstract}

\section{Streszczenie}

Wybór odpowiedniego postępowania z pacjentami przyjmującymi doustne leki przeciwzakrzepowe, którzy są poddawani planowym zabiegom chirurgicznym, stanowi częsty problem w praktyce klinicznej. Wielu chorych stosuje doustne leki przeciwzakrzepowe z powodu migotania przedsionków, posiadania mechanicznych protez zastawkowych lub choroby zakrzepowo-zatorowej. Część z tych osób każdego roku poddawanych jest zabiegom chirurgicznym. Istotne jest ocenienie u nich ryzyka krwawienia związanego z procedura chirurgiczną, ryzyka krwawienia związanego z przyimowaniem doustnych leków przeciwzakrzepowych, a także ryzyka związanego z odstawieniem tych leków i wystąpieniem niekorzystnych powikłań w okresie okołooperacyjnym, takich jak udar niedokrwienny mózgu lub zakrzepica w stentach w naczyniach wieńcowych. Poniższy artykuł stanowi podsumowanie doniesień na temat zasad odstawiania doustnych leków przeciwzakrzepowych przed planowymi zabiegami chirurgicznymi.

\section{Introduction}

Interruption of long-term therapy with oral anticoagulants $(\mathrm{OAC})$ in patients undergoing elective surgical procedures is a common clinical dilemma. It has been estimated that 7 million people worldwide are receiving long-term therapy with oral anticoagulants [1]. Indications for OAC include atrial fibrillation, mechanical heart valves, venous or arterial thromboembolism, or ventricular assist devices. Each year around $15-20 \%$ of these patients will undergo invasive procedures [2-4]. This accounts for 1.4 million patients annually, who might require temporary cessation of OAC. The number is likely to increase as the preva- lence of many of comorbidities being indications for $\mathrm{OAC}$ is rising.

There are many possible scenarios depending on the classification of the surgical procedure, indications and type of OAC, clinical profile of the patient, and their individual thromboembolic and bleeding risk factors. Best practices are uncertain, the perioperative protocol differs between institutions, and multiple specialists are often involved. There is no universal expert consensus. To facilitate a decision-making process strategies covering atrial fibrillation (AF) patients have recently been proposed by the American College of Cardiology [5] and the European Heart Rhythm Association [6]. Minimal guidance for peri- 
procedural management of patients taking OAC for indications other than AF are found in the European Society of Cardiology guidelines [7, 8], as well as in American expert documents $[9,10]$.

The aim of this review is to summarise current knowledge and discuss recommendations on interruption of anticoagulation in patients undergoing elective surgical procedures. We specifically address the following questions: how to estimate patient- and procedure-related bleeding risk, how to estimate patients' thromboembolic risk, whether and when to stop and restart OAC, and whether and how to use parenteral agents for bridging therapy.

\section{How to estimate patient- and procedure- related bleeding risk}

The obvious argument for OAC interruption is the increased risk of bleeding associated with surgical procedure in anticoagulated patients. Bleeding complications are associated with an increased risk for short- and long-term adverse outcomes [11]. It may be partially related to the longer period of increased thromboembolic risk following the likely need of discontinuation of $\mathrm{OAC}$ if the patient bleeds from the procedure. Despite the fact that some standardised definitions for bleeding have been proposed [11], they have not been consistently applied in clinical trials evaluating procedural risk [5]. In general, bleeding complications are at least 3-4 times more frequent than thromboembolic events $[2,4,12,13]$.

The overall bleeding risk is related to the type of interventional procedure as well as the patient's clinical profile and comorbidities. The first step should be to identify the risk of bleeding associated with the interventional procedure. The bleeding risk considerations should include the frequency of bleeding related to the specific procedure, the possibility of achieving adequate local haemostasis, and the clinical consequences if the bleeding occurs (for example involving a critical anatomical site). There are many types of interventions that should not comprise OAC interruption. Classification of interventions have been proposed by different medical associations and societies $[5,6]$.

There are some procedures that carry very low or very high bleeding risk. For the purpose of further considerations in the setting of OAC interruption prior to surgery or intervention, bleeding risk should be divided into three categories: minimal, low, and higher than low. Interventions with minor bleeding risk are, e.g. implant positioning or extraction of 1-3 teeth. Interventions with high bleeding risk include, e.g. thoracic, abdominal surgery, major orthopaedic surgery, and complex left- sided ablation. If the risk is higher than low, OAC interruption is necessary. If it is minimal or low, OAC discontinuation may be considered, depending on other factors.
It is important to evaluate patient-related bleeding risk in the next step. The popular HAS-BLED scale is useful. The HAS-BLED score assigns one point each for hypertension, abnormal renal function, abnormal liver function, stroke, bleeding tendency, labile INRs, old age, antiplatelet drugs, and alcohol use. A HASBLED score $\geq 3$ is commonly interpreted as being associated with high risk of bleeding, and it was highly predictive of bleeding events in the national multicentre registry of patients who required interruption of OAC for an elective invasive procedure [14]. Therefore, patients with three or more points should be considered as being at high risk of bleeding complications. As proposed by the American College of Cardiology expert task force, additional items that should be included in the periprocedural management algorithm are: prior bleeding event within 3 months, quantitative or qualitative platelet abnormality, international normalized ratio (INR) above the therapeutic range at the time of the procedure, bleeding history from previous bridging, or bleed history from a similar procedure [5].

\section{How to estimate patients' thromboembolic risk}

OAC interruption may transiently increase the risk of thromboembolic complications. Major surgical procedures may additionally induce prothrombotic state. A hypercoagulant condition can be further elevated due to rebound phenomena that occur after warfarin withdrawal [15]. However, the actual rate of perioperative thromboembolism is relatively low: around $0.5 \%$ for unbridged OAC interruption based on observational data [4]. Higher risk is observed for mechanical heart valves (around 1\%) $[4,16]$ and lower for venous thromboembolism (VTE) (around 0.2\%) [17]. For AF it may be as high as $0.5-0.6 \%[2,12]$ and is associated with patients' predicted stroke risk. In ORBIT-AF the periprocedural cohort observed a $0.35 \%$ 30 -day stroke rate that was similar to the estimated 30 -day stroke risk based on the average $\mathrm{CHADS}_{2}$ VASc score in this cohort [2]. For vitamin K antagonist (VKA)-treated patients the real-life reported average time in therapeutic range rarely exceeds $65 \%[18,19]$. This translates into almost 3 months a year that an average patient spends within the subtherapeutic range. The length of time that is required for OAC discontinuation due to an invasive procedure is typically a few days. Not to mention that even in North America and Western Europe less than two-thirds of patients with $\mathrm{AF}$ and guideline indications for OAC actually receive them [19].

To access patient thromboembolic risk, we need to determine their indications for OAC. First, it is rational to confirm indications or verify whether they are transient. The next step is to identify the patients having truly high risk of thromboembolic events. 
Patients with mechanical heart valves or left ventricular assist devices are generally considered as having high thromboembolic risk, despite the fact that cumulative thromboembolic complications rates (ischaemic stroke and pump thrombosis) have been reported to be relatively modest - experienced by $1.5 \%$ of patients with HeartMate II LVADs over the course of a year [20].

Patients with newly inserted biological prosthetic heart valves or mitral valvular repair within the past 3 months are also considered as high risk regarding thromboembolic complications. The same applies to the patients with thrombophilia in whom discontinuation of VKA is hazardous as well [7].

Patients with AF are a more heterogeneous group, and the best way to estimate their risk of stroke is by using the $\mathrm{CHA}_{2} \mathrm{DS}_{2}$-VASc score, which includes the following clinical variables: congestive heart failure, hypertension, age, diabetes, prior stroke, other vascular diseases, and sex. Although this scale has not been prospectively validated in the perioperative scenario in any large clinical trial, it has been widely used in this setting, and expert guidelines have endorsed its use $[5,7]$. It has been proposed that four points should be the cut-off value discriminating high-risk patients. Patients with exactly four points are a borderline group and should be assessed individually.

The next problem concerns patients with VTE. Thromboembolic risk is greater in the immediate period following a thromboembolic event and declines over time. The perioperative risk of VTE is greatest in individuals with an event (e.g. deep vein thrombosis, pulmonary embolus) within the prior 3 months and those with a history of VTE associated with a high-risk inherited thrombophilia. Thus, patients who require surgery within the first 3 months following an episode of VTE are likely to benefit from delaying elective surgery, even if the delay is only for a few weeks. The recurrence risk for individuals with a recent VTE is highest within the initial 3 to 4 weeks and diminishes over the following 2 months [21]. Thus, patients with a recent arterial embolism are likely to benefit from delaying elective surgery, if such a delay is possible.

\section{Interruption of anticoagulation}

When the thromboembolic and bleeding risks have been estimated, a decision can be made about whether the anticoagulant should be interrupted or continued. Data comparing the relative benefits of continuing anticoagulation versus interrupting an anticoagulant are limited. Many interventions can be performed without stopping the anticoagulant, to prevent complications such as stroke or death. Any manipulation of the dose of anticoagulants, and especially their withdrawal for a few days, are only allowed if the procedure is absolutely necessary. The procedure should be performed as late as possible from the thromboembolic event, but the final decision about the time of surgery remains the responsibility of the surgeon.

There are three main categories of procedures with different risks of bleeding complications. The minor or low risk of bleeding includes procedures in which the incidence of major bleeding is low or the surgeon can easily control haemostasis in the operating field. These include, for example, the extraction of 1-3 teeth and ophthalmic surgery. Treatments with a high risk of bleeding include, for example, large orthopaedic surgery or abdominal surgery. In general, the anticoagulant must be discontinued if the surgical bleeding risk is high [6]. Those at very high or high thromboembolic risk should limit the period without anticoagulation to the shortest possible interval; in some cases, this involves the use of a bridging agent. If the surgical bleeding is low, we can continue taking anticoagulants.

\section{Interruption of vitamin $\mathrm{K}$ antagonist}

Patients qualified for surgery with high risk of bleeding require discontinuation of warfarin for 5 days, and acenocoumarol 2-3 days before surgery. INR measurement is made $24 \mathrm{~h}$ before the procedure; if the INR value exceeds 1.5 we should wait an additional day or give a small dose of vitamin K (1-2 mg) p.o. [21]. Higher doses of vitamin $\mathrm{K}$ given intravenously induce a resistance to VKA for a few days, which may occur after its re-inclusion after the procedure. At the end of the operation, VKA may be taken if the local haemostasis is provided, usually after $24-48 \mathrm{~h}$ (at the earliest $12 \mathrm{~h}$ after surgery) [21]. If discontinuation of VKA for a few days is too risky (e.g. in a patient with high thromboembolic risk), in the periprocedural period, bridging therapy with low-molecular-weight heparin (LMWH) administered subcutaneously or unfractionated heparin administered intravenously is used. Administration of heparin begins 3-4 days before the procedure, usually $24 \mathrm{~h}$ after the last dose of warfarin (in the case of acenocoumarol - 2-3 days before the procedure) [22].

If a patient taking VKA requires an emergency invasive procedure, it is necessary to quickly normalise the activity of the coagulation system. If INR is increased, the ACCP guidelines recommend the transfusion of fresh frozen plasma or prothrombin complex concentrate, simultaneously with vitamin $\mathrm{K}$ at a dose of 2.5-5 mg PO or IV [10]. However, a sudden inversion of VKA activity is not possible by administering vitamin $\mathrm{K}$ alone. Instead of a concentrate of prothrombin complex factors, recombinant factor VIIa (NovoSeven) can be administered, especially in the case of simultaneous bleeding [23]. This strategy is expensive and can promote thromboembolism complications; therefore, it is a good option for persistent 
bleeding that cannot be cured by other treatments. NovoSeven should not be used to reverse the anticoagulant effect of VKA. It is recommended that the INR be checked at least every $6-12 \mathrm{~h}$, as long as the INR is not normalised.

\section{Interruption of NOAC}

The decision to stop new anticoagulants before planned surgery is determined by two factors: The risk of bleeding associated with invasive surgery (large or small) and renal function. Rivaroxaban, and dabigatran may accumulate in the body in the case of impaired renal function - these drugs are excreted by the kidneys in $66 \%$ and $80 \%$ of cases [24]. The activity of warfarin or acenocoumarol does not depend on kidney function. In the case of rivaroxaban, liver function parameters should also be determined to exclude serious organ damage (ALT $>3 \times$ ). Severe liver damage may slow the elimination of rivaroxaban, but in practice the effect of this factor in the context of surgery is negligible [24].

The time to stop therapy of NOAC is summarised in Table 1.

In contrast to patients treated with warfarin or acenocoumarol with high or medium thromboembolic risk, who are advised to use bridging therapy, patients with new anticoagulants do not require such treatment [25]. If a patient with atrial fibrillation has a high risk of thromboembolism, especially with a cerebral ischaemic event in the last 3 months prior to invasive surgery, heparin may be considered after surgery if the physician is concerned that the full dose of rivaroxaban (or dabigatran) could expose the patient to an excessive risk of bleeding. In the US, it is suggested that lower doses of drugs be used initially, for example $75 \mathrm{mg}$ dabigatran, but this approach is currently considered non-standard, and in Polish conditions, administration of low-molecular-weight heparin seems to be a safer option.

Patients who require urgent surgery during NOAC need proper treatment. If the last dose of dabigatran or rivaroxaban was taken more than $2-4 \mathrm{~h}$ ago, it is recommended that activated carbon be administered.
If the drug has been used more than $4 \mathrm{~h}$ earlier, activated carbon will not improve the situation, and surgery for life indications may be associated with a high risk of bleeding. Time up to $48 \mathrm{~h}$ and more from the last dose of dabigatran or rivaroxaban may not be sufficient for normalisation of coagulation when renal function is impaired. How can we check whether the patient remains under the action of the drug, especially when contact with him/her is difficult and information about taking of the drug is impossible? Routinely available coagulation parameters are not used to monitor anticoagulant effects of either dabigatran or rivaroxaban. Specific tests, such as the modified thrombin time and anti-Xa activity, are not always available. Before surgery, it is worth determining the simple parameters of the coagulation system, which is activated partial thromboplastin time (APTT) in the case of dabigatran and prothrombin time in the case of rivaroxaban. If the APTT is the reference limit $(<40 \mathrm{~s})$, the anticoagulant effect of dabigatran has passed and the patient can be safely operated. Similarly, a prothrombin time $<15 \mathrm{~s}$ shows that the risk of bleeding is similar to the risk in people not using anticoagulants [25]. The prolongation of these times indicates the presence of active drug in the blood. When surgery cannot be delayed, especially if no more than $6 \mathrm{~h}$ have passed since taking the drug and the results of basic laboratory tests show a two-fold prolongation (APTT $>80 \mathrm{~s}$ for dabigatran and INR $>1.5$ for rivaroxaban), before the operation, the anticoagulant effect should be reversed. However, specific preparations that reverse the effects of dabigatran and rivaroxaban are not currently available. For comparison, to reverse the activity of warfarin or acenocoumarol a concentrate of prothrombin complex factors must be used (factor II, VII, IX, and X - Beriplex, Prothromplex). The efficacy of prothrombin complex concentrate in reversing the action of new anticoagulants is limited. Data from experimental studies suggest that in reversing the anticoagulant effect of dabigatran, the concentrate of activated prothrombin complex agents (e.g. FEIBA) may be more effective. However, the drug is expensive, and in most surgical departments it is not available [26]. In the case of dabigatran, we can increase

Table 1. Timing of last non-vitamin $\mathrm{K}$ antagonist oral anticoagulant intake before start of an elective intervention [6]

\begin{tabular}{|c|c|c|c|c|}
\hline \multirow[t]{2}{*}{$\mathrm{CrCl}[\mathrm{ml} / \mathrm{min}]$} & \multicolumn{2}{|c|}{ Dabigatran } & \multicolumn{2}{|c|}{ Apixaban - edoxaban - rivaroxaban } \\
\hline & Low risk & High risk & Low risk & High risk \\
\hline$\geq 80$ & $» 24 \mathrm{~h}$ & $» 48 \mathrm{~h}$ & $» 24 \mathrm{~h}$ & $» 48 \mathrm{~h}$ \\
\hline $50-79$ & $» 36 \mathrm{~h}$ & $» 72 \mathrm{~h}$ & $» 24 \mathrm{~h}$ & $» 48 \mathrm{~h}$ \\
\hline $30-49$ & » $48 \mathrm{~h}$ & » $96 \mathrm{~h}$ & $» 24 \mathrm{~h}$ & » $48 \mathrm{~h}$ \\
\hline $15-29$ & Not indicated & Not indicated & $» 36 \mathrm{~h}$ & $» 48 \mathrm{~h}$ \\
\hline$<15$ & \multicolumn{4}{|c|}{ No official indication for use } \\
\hline
\end{tabular}

$\mathrm{CrCl}$-creatinine clearance. 
diuresis by giving a large volume of fluids with the diuretic drug [25]. Dabigatran may also be removed by haemodialysis. A much more sensitive parameter for the activity of dabigatran is the thrombin time. A specific test based on thrombin time determination in patients treated with dabigatran, called HemoClot, is available. The administration of vitamin $\mathrm{K}$ or protamine sulphate is definitely discouraged, because it is completely ineffective in reversing the anticoagulant effect of dabigatran and rivaroxaban [27].

After surgery, if local haemostasis is satisfactory, dabigatran or rivaroxaban may be restarted: after $24 \mathrm{~h}$ in the case of surgery with low risk of bleeding (after minor surgery, e.g. gastroscopy, it may be possible to return to the drug after only $4-6 \mathrm{~h}$ ) and after $48 \mathrm{~h}$ for an operation with a high risk of bleeding. It is the best to start administering these drugs after the procedure, at the earliest after $12 \mathrm{~h}$. The full anticoagulant effect is observed after $2 \mathrm{~h}$, so local haemostasis is essential. If local haemostasis is not achieved after surgery, the administration of dabigatran or rivaroxaban should be delayed, also for the reasons listed earlier. If, after surgery, persistent bleeding occurs after using a new anticoagulant, fresh frozen plasma is recommended. In addition to the red blood cell concentrates, a fourcomponent concentrate of prothrombin factors is also used in large amounts, optionally a concentrate of the plates (if the number of plates is too small). In addition, the use of rFVIIa beyond the registration indications (off-label) is also suggested (also in the dabigatran characteristics), although arterial thrombosis may develop as a complication [23].

In summary, new anticoagulants increase the risk of haemorrhagic complications also in the periprocedural period. However, the management is easier with dabigatran or rivaroxaban than with the use of VKA. Compliance with the recommended duration of drug interruption, taking into account the glomerular filtration rate (GFR) value, allows in most cases the prevention of dangerous bleeding.

\section{Bridging anticoagulation}

Anticoagulation bridge therapy refers to the use of a short-acting parenteral anticoagulant - unfractionated heparin (UFH) or LMWH - during periods of inadequate anticoagulation [22]. The aim of bridging is to minimise the time the patient is not anticoagulated, thereby minimising the risk for perioperative thromboembolism. However, this needs to be balanced with the importance of reducing the risk of postoperative bleeding. A small delay in resumption of postoperative anticoagulation is preferable to premature initiation of postoperative bridging that results in bleeding, which will lengthen the period without an anticoagulant and increase thromboembolic risk. Bridging anticoagulation may be appropriate in patients who will have a very high thromboembolic risk with pro- longed interruption of their anticoagulant (generally a VKA). Individual patient comorbidities that increase bleeding risk may also need to be considered because an increased postoperative bleeding risk may be a reason to avoid bridging. It is suggested that bridging be used in individuals taking warfarin for one of the following conditions [28]:

- Embolic stroke or systemic embolic event within the previous 3 months,

- Mechanical mitral valve,

- Mechanical aortic valve and additional stroke risk factors,

- Atrial fibrillation and very high risk of stroke (e.g. $\mathrm{CHADS}_{2}$ score of 5 or 6 , stroke or systemic embolism within the previous 12 weeks, concomitant rheumatic valvular heart disease with mitral stenosis),

- VTE within the previous 3 months (preoperative and postoperative bridging),

- Previous thromboembolism during interruption of chronic anticoagulation.

For most patients with atrial fibrillation the bridging anticoagulation is not necessary. Generally, it is recommended to avoid bridging therapy in patients with low thromboembolic risk (e.g. lower $\mathrm{CHADS}_{2}$ or $\mathrm{CHA}_{2} \mathrm{DS}_{2}$-VASc score and higher the risk of bleeding). This practice is supported by the BRIDGE trial, which randomly assigned 1884 patients with atrial fibrillation, who required interruption of warfarin for an invasive procedure to receive bridging anticoagulation with the LMW heparin (dalteparin) versus placebo [13]. The incidence of arterial thromboembolic events 30 days after the procedure was similar in those who received dalteparin or placebo. The incidence of major bleeding (a secondary outcome) was higher in those who received dalteparin, although none of the bleeds was fatal. Patients were excluded from the trial if they had a mechanical heart valve or a recent (within the previous 12 weeks) stroke, embolism, or transient ischaemic attack. Bridging versus no bridging did not affect major outcomes in patients who required a major procedure during participation in large anticoagulation trials for atrial fibrillation, including the RE-LY (warfarin versus dabigatran), ROCKET-AF (warfarin versus rivaroxaban), and ARISTOTLE (warfarin versus apixaban) trials [28-30]. In the RE-LY trial, patients receiving warfarin had more thromboembolic events associated with bridging than with non-use of bridging; patients who received bridging also had a higher risk of major bleeding [28]. In the ORBIT-AF study 2200 of 7372 individuals (30\%) had interruption of anticoagulation for a procedure [2]. Bridging was used in $24 \%$ of these interruptions, especially in patients with a history of stroke or a mechanical heart valve and/or receiving warfarin; bleeding events were more common in individuals who received bridging compared with those who did not receive bridging. A composite endpoint that included major bleeding, myocardial infarction, stroke, systemic embolism, 
hospitalisation, or death within 30 days was also higher in those who received bridging. In the Dresden NOAC registry, over 800 patients who were receiving dabigatran, rivaroxaban, or apixaban for any indication and underwent an invasive procedure had similar rates of major cardiovascular events if they received bridging, no bridging, or no anticoagulant discontinuation [31]. Bridging was not an independent risk factor for major bleeding; however, individuals undergoing major procedures were more likely to receive bridging and to have major bleeding.

Bridging is generally not used for the shorter-acting direct oral thrombin inhibitors or factor Xa inhibitors. However, bridging may be appropriate for individuals receiving these agents, who have a very high thromboembolic risk and a more prolonged interruption of their anticoagulant (e.g. due to postoperative intestinal ileus that prevents oral intake).

\section{Special types of procedures}

\section{Pacemaker and implantable cardioverter defibrillator implantation}

While there are many data surrounding the periprocedural use of warfarin for permanent pacemaker (PPM)/implantable cardioverter defibrillator (ICD) implantation, data on NOAC use in this setting are limited. Recent studies suggest that the clinical practice is to interrupt NOAC therapy prior to pacemaker and ICD implantation [32]. For NOAC-treated patients, there is no reason to deviate from the global scheme, with timed cessation before intervention, without bridging, and restarting a few hours up until 2 days afterwards (depending on $\mathrm{CHA}_{2} \mathrm{DS}_{2}$-VASc risk). The risk of pocket haematomas is $2-3 \%$ with uninterrupted oral anticoagulation [33]. The use of NOACs during $\mathrm{PPM} / \mathrm{ICD}$ placement confers an intermediate risk of bleeding [34]. With regard to bridging, multiple studies, including a prospective randomised trial as well as a meta-analysis, have demonstrated that uninterrupted warfarin therapy results in significantly fewer pocket hematomas versus bridging with heparinoids [35]. The Bruise Control 2 trial showed very low risk of pocket haematoma regardless of whether NOAC was interrupted or not, and very low risk of thromboembolic complications. Both strategies seem to be comparable, and the decision should be made individually [36]. However, the study did not have adequate statistical power to conclude that the differences were not significant. In light of these studies, it appears that the risks of bridging outweigh the benefits during device placement, especially considering the short period of unprotected time given the rapid clearance of NOACs.

\section{Atrial fibrillation ablation procedures}

Pulmonary vein isolation (PVI) is an intervention with a risk of serious bleeding. Tamponade or haemo- thorax may occur secondarily to transseptal puncture or extensive manipulation and ablation in the left atrium [37]. Separate data on major groin bleedings were not presented but are not uncommon. On the other hand, ablation is performed in a pro-thrombotic setting, while endocardial ablation lesions further increase thromboembolic risk. Recent international consensus statements recommend performance of PVI in VKA-treated patients without VKA interruption, because such a strategy is associated not only with fewer thromboembolic events but also with less bleeding [37]. These expert recommendations have been confirmed in a large controlled trial comparing interrupted and uninterrupted warfarin therapy [38]. There has been a recent shift towards performing AF ablation on uninterrupted VKA therapy with a target INR of 2.0-2.5. Whether such an approach is safe in patients on NOAC therapy is less clear. Most studies recommend ablation during use of NOAC. A number of factors should be considered for the timing of last intake, such as renal function, $\mathrm{CHA}_{2} \mathrm{DS}_{2}$-VASc risk of the patient, experience of the operator, type and extent of additional ablation beyond PVI, and the presence of periprocedural imaging to guide transseptal puncture [6]. Meta-analysis data indicate that a last intake of NOAC $24 \mathrm{~h}$ before the procedure is a viable strategy. Continued intake until the evening before the procedure or even the morning of the procedure seems to be equally safe, especially in experienced centres, but more data are needed to make statements on the best strategy. When NOAC is last taken $\geq 36 \mathrm{~h}$ before the intervention, a transoesophageal echocardiography (TOE) should be considered before ablation. The same applies if adherence to correct NOAC intake in the weeks before ablation is doubtful. Transoesophageal echocardiography can be performed shortly before the ablation procedure or at its onset, so that it can also guide transseptal puncture. Note that some operators prefer systematic TOE in every patient with elevated $\mathrm{CHA}_{2} \mathrm{DS}_{2}$-VASc risk at the initiation of the ablation procedure [6]. Non-vitamin K antagonist oral anticoagulant intake can be resumed 3-4 h after sheath removal if adequate haemostasis and the absence of pericardial effusion have been confirmed.

\section{Gaps in evidence, ongoing clinical trials, and future directions}

There is a gap in evidence of thromboembolic risk in the very high-risk patients interrupting anticoagulation, including those with mechanical heart valves and $\mathrm{AF}$ with numerous thromboembolic risk factors. Patients with mechanical heart valves were excluded from the BRIDGE trial, and only around 3\% of the patients included had a $\mathrm{CHADS}_{2}$ score of 5-6 [13]. In large clinical trials the mean $\mathrm{CHADS}_{2}$ score ranged from just 2.1 in ARISTOTLE [39] and RE-LY [40] to 2.8 in ENGAGE-AF [41], with somewhat high- 
er risk in patients who enrolled in ROCKET-AF [42] (mean $\mathrm{CHADS}_{2}$ score, 3.5). Any sub-analyses cannot cover sufficiently those very high-risk patients; therefore, evidence guiding perioperative anticoagulation management in this subset of patients is needed [29]. The ongoing double-blind randomised control trial of Safety and Effectiveness of LMWH versus Placebo Bridging Therapy for Patients on Long-Term Warfarin Requiring Temporary Interruption of Warfarin (PERIOP 2) will specifically focus on AF patients with prosthetic heart valves and another major risk factors for stroke $[3,43]$. The results of this study are expected late in 2018 [44] and are anticipated to provide important guidance on periprocedural management of anticoagulation in high-risk patients with AF and mechanical heart valves.

Research on perioperative management of NOACs is also evolving. Current recommendations are largely based on renal clearance of the agent and the bleeding risk of the procedure [3]. NOACs allow shorter interruption periods, but it is uncertain if they should be stopped even for low bleeding-risk procedures. Their safety has recently been improved with the introduction of drug-specific antidotes, which will have an influence on recommended perioperative strategies [45, 46]. Few prospective data on the perioperative management of NOAC are available [6]. The aim of the Perioperative Anticoagulant Use for Surgery Evaluation (PAUSE) study is to establish a safe, standardised protocol for the perioperative management of patients with $\mathrm{AF}$, who are receiving either dabigatran, rivaroxaban, or apixaban and require an elective surgery or procedure [47]. The study is currently recruiting patients, and results are expected in December 2018 [48]. It will provide more information on the relation between last intake, preprocedural plasma level, and clinical outcomes [49].

\section{Acknowledgments}

The project is financed by the Minister of Science and Higher Education's program under the name "Regional Initiative of Excellence" in the years 2019-2022, contract number 024/RID/2018/19, funding amount PLN 11999 000.00.

\section{Conflict of interest}

The authors declare no conflict of interest.

\section{References}

1. Nutescu EA, Wittkowsky AK, Burnett A, Merli GJ, Ansell JE, Garcia DA. Delivery of optimized inpatient anticoagulation therapy: consensus statement from the anticoagulation forum. Ann Pharmacother 2013; 47: 714-724.

2. Steinberg BA, Peterson ED, Kim S, Thomas L, Gersh BJ, Fonarow GC, Kowey PR, Mahaffey KW, Sherwood MW, Chang P, Piccini JP, Ansell J; Outcomes Registry for Better Informed Treatment of Atrial Fibrillation Investigators and Patients.Use and outcomes associated with brid- ging during anticoagulation interruptions in patients with atrial fibrillation: findings from the Outcomes Registry for Better Informed Treatment of Atrial Fibrillation (ORBIT-AF). Circulation 2015; 131: 488-494.

3. Garwood CL, Korkis B, Grande D, Hanni C, Morin A, Moser LR. Anticoagulation bridge therapy in patients with atrial fibrillation: recent updates providing a rebalance of risk and benefit. Pharmacotherapy 2017; 37: 712-724.

4. Rechenmacher SJ, Fang JC. Bridging anticoagulation: primum non nocere. J Am Coll Cardiol 2015; 66: 1392-1403.

5. Doherty JU, Gluckman TJ, Hucker WJ, Januzzi JL, Ortel TL, Saxonhouse SJ, Spinler SA. 2017 ACC Expert Consensus Decision Pathway for Periprocedural Management of Anticoagulation in Patients With Nonvalvular Atrial Fibrillation: A Report of the American College of Cardiology Clinical Expert Consensus Document Task Force. J Am Coll Cardiol 2017; 69: 871-898.

6. Steffel J, Verhamme P, Potpara TS, Albaladejo P, Antz M, Desteghe L, Haeusler KG, Oldgren J, Reinecke H, Roldan-Schilling V, Rowell N, Sinnaeve P, Collins R, Camm AJ, Heidbüchel H; ESC Scientific Document Group. The 2018 European Heart Rhythm Association Practical Guide on the use of non-vitamin $\mathrm{K}$ antagonist oral anticoagulants in patients with atrial fibrillation. Eur Heart J 2018; 39: 1330-1393.

7. Kristensen SD, Knuuti J, Saraste A, Anker S, Bøtker HE, Hert SD, Ford I, Gonzalez-Juanatey JR, Gorenek B, Heyndrickx GR, Hoeft A, Huber K, Iung B, Kjeldsen KP, Longrois D, Lüscher TF, Pierard L, Pocock S, Price S, Roffi M, Sirnes PA, Sousa-Uva M, Voudris V, Funck-Brentano C; Authors/Task Force 2014 ESC/ESA Guidelines on non-cardiac surgery: cardiovascular assessment and management: The Joint Task Force on non-cardiac surgery: cardiovascular assessment and management of the European Society of Cardiology (ESC) and the European Society of Anaesthesiology (ESA). Eur Heart J 2014; 35: 2383-2431.

8. Baumgartner H, Falk V, Bax JJ, De Bonis M, Hamm C, Holm PJ, Iung B, Lancellotti P, Lansac E, Rodriguez Muñoz D, Rosenhek R, Sjögren J, Tornos Mas P, Vahanian A, Walther T, Wendler O, Windecker S, Zamorano JL; ESC Scientific Document Group. 2017 ESC/EACTS Guidelines for the management of valvular heart disease. Eur Heart J 2017; 38: 2739-2791.

9. Nishimura RA, Otto CM, Bonow RO, Carabello BA, Erwin JP, Guyton RA, O'Gara PT, Ruiz CE, Skubas NJ, Sorajja P, Sundt TM 3rd, Thomas JD; ACC/AHA Task Force Members. 2014 AHA/ACC guideline for the management of patients with valvular heart disease: a report of the American College of Cardiology/American Heart Association Task Force on Practice Guidelines. J Am Coll Cardiol 2014; 63: e57-e185.

10. Douketis JD, Spyropoulos AC, Spencer FA, Mayr M, Jaffer AK, Eckman MH, Dunn AS, Kunz R. Perioperative management of antithrombotic therapy: Antithrombotic Therapy and Prevention of Thrombosis, 9th ed: American College of Chest Physicians Evidence-Based Clinical Practice Guidelines. Chest 2012; 141 (2 Suppl): e326S-e350S.

11. Mehran R, Rao SV, Bhatt DL, Gibson CM, Caixeta A, Eikelboom J, Kaul S, Wiviott SD, Menon V, Nikolsky E, Serebruany V, Valgimigli M, Vranckx P, Taggart D, Sabik JF, Cutlip DE, Krucoff MW, Ohman EM, Steg PG, White $\mathrm{H}$. Standardized bleeding definitions for cardiovascu- 
lar clinical trials: a consensus report from the Bleeding Academic Research Consortium. Circulation 2011; 123: 2736-2747.

12. Siegal D, Yudin J, Kaatz S, Douketis JD, Lim W, Spyropoulos AC. Periprocedural heparin bridging in patients receiving vitamin $\mathrm{K}$ antagonists: systematic review and meta-analysis of bleeding and thromboembolic rates. Circulation 2012; 126: 1630-1639.

13. Douketis JD, Spyropoulos AC, Kaatz S, Becker RC, Caprini JA, Dunn AS, Garcia DA, Jacobson A, Jaffer AK, Kong DF, Schulman S, Turpie AG, Hasselblad V, Ortel TL; BRIDGE Investigators. Perioperative bridging anticoagulation in patients with atrial fibrillation. $\mathrm{N}$ Engl J Med 2015; 373: 823-833.

14. Omran H, Bauersachs R, Rübenacker S, Goss F, Hammerstingl $\mathrm{C}$. The HAS-BLED score predicts bleedings during bridging of chronic oral anticoagulation. Results from the national multicentre BNK Online bRiDging REgistRy (BORDER). Thromb Haemost 2012; 108: 65-73.

15. Palareti G, Legnani C. Warfarin withdrawal. Pharmacokinetic-pharmacodynamic considerations. Clin Pharmacokinet 1996; 30: 300-313.

16. Daniels PR, McBane RD, Litin SC, Ward SA, Hodge DO, Dowling NF, Heit JA. Peri-procedural anticoagulation management of mechanical prosthetic heart valve patients. Thromb Res 2009; 124: 300-305.

17. Clark NP, Witt DM, Davies LE, Saito EM, McCool KH, Douketis JD, Metz KR, Delate T. Bleeding, recurrent venous thromboembolism, and mortality risks during warfarin interruption for invasive procedures. JAMA Intern Med 2015; 175: 1163-1168.

18. Pinho-Costa L, Moreira S, Azevedo C, Azevedo P, Castro E, Sousa H, Melo M. APOLLO I: Anticoagulation control in atrial fibrillation. Rev Port Cardiol 2015; 34: 337 345.

19. Oldgren J, Healey JS, Ezekowitz M, Commerford P, Avezum A, Pais P, Zhu J, Jansky P, Sigamani A, Morillo CA, Liu L, Damasceno A, Grinvalds A, Nakamya J, Reilly PA, Keltai K, Van Gelder IC, Yusufali AH, Watanabe E, Wallentin L, Connolly SJ, Yusuf S; RE-LY Atrial Fibrillation Registry Investigators. Variations in cause and management of atrial fibrillation in a prospective registry of 15400 emergency department patients in 46 countries: the RE-LY Atrial Fibrillation Registry. Circulation 2014; 129: $1568-1576$

20. Boyle AJ, Russell SD, Teuteberg JJ, Slaughter MS, Moazami N, Pagani FD, Frazier OH, Heatley G, Farrar DJ, John R. Low thromboembolism and pump thrombosis with the heartmate ii left ventricular assist device: analysis of outpatient anti-coagulation. J Heart Lung Transplant 2009; 28: 881-887.

21. Oprea AD, Noto CJ, Halaszynski TM. Risk stratification, perioperative and periprocedural management of the patient receiving anticoagulant therapy. J Clin Anesth 2016; 34: 586-99.

22. Garwood CL, Korkis B, Grande D, Hanni C, Morin A, Moser LR. Anticoagulation bridge therapy in patients with atrial fibrillation: recent updates providing a rebalance of risk and benefit. Pharmacotherapy 2017; 37: 712-724.

23. Warkentin TE, Margetts P, Connolly SJ, Lamy A, Ricci C, Eikelboom JW. Recombinant factor VIIa (rFVIIa) and hemodialysis to manage massive dabigatran-associated postcardiac surgery bleeding. Blood 2012; 119: 2172-2174.
24. Riva N, Lip GY. A new era for anticoagulation in atrial fibrillation. Which anticoagulant should we choose for long-term prevention of thromboembolic complications in patients with atrial fibrillation? Pol Arch Med Wewn 2012; 122: 45-53.

25. Douketis JD. Dabigatran as anticoagulant therapy for atrial fibrillation. Which patients should receive it, which patients may not need it, and other practical aspects of patient management. Pol Arch Med Wewn 2011; 121: 73-80.

26. Alberts MJ, Bernstein RA, Naccarelli GV, Garcia DA. Using dabigatran in patients with stroke: a practical guide for clinicians. Stroke 2012; 43: 271-279.

27. Schulman S, Crowther MA. How I anticoagulate in 2012, new and old anticoagulant agents, and when and how to switch. Blood 2012; 119: 526-529.

28. Healey JS, Eikelboom J, Douketis J, Wallentin L, Oldgren J, Yang S, Themeles E, Heidbuchel H, Avezum A, Reilly P, Connolly SJ, Yusuf S, Ezekowitz M; RE-LY Investigators. Periprocedural bleeding and thromboembolic events with dabigatran compared with warfarin: results from the Randomized Evaluation of Long-Term Anticoagulation Therapy (RE-LY) randomized trial. Circulation 2012; 126: 343-348.

29. Sherwood MW, Douketis JD, Patel MR, Piccini JP, Hellkamp AS, Lokhnygina Y, Spyropoulos AC, Hankey GJ, Singer DE, Nessel CC, Mahaffey KW, Fox KA, Califf RM, Becker RC; ROCKET AF Investigators. Outcomes of temporary interruption of rivaroxaban compared with warfarin in patients with nonvalvular atrial fibrillation: results from the rivaroxaban once daily, oral, direct factor Xa inhibition compared with vitamin $\mathrm{K}$ antagonism for prevention of stroke and embolism trial in atrial fibrillation (ROCKET AF). Circulation 2014; 129: 1850-1859.

30. Garcia D, Alexander JH, Wallentin L, Wojdyla DM, Thomas L, Hanna M, Al-Khatib SM, Dorian P, Ansell J, Commerford P, Flaker G, Lanas F, Vinereanu D, Xavier D, Hylek EM, Held C, Verheugt FW, Granger CB, Lopes RD. Management and clinical outcomes in patients treated with apixaban vs warfarin undergoing procedures. Blood 2014; 124: 3692-3698.

31. Beyer-Westendorf J, Gelbricht V, Förster K, Ebertz F, Köhler C, Werth S, Kuhlisch E, Stange T, Thieme C, Daschkow K, Weiss N. Peri-interventional management of novel oral anticoagulants in daily care: results from the prospective Dresden NOAC registry. Eur Heart J 2014; 35: 1888.

32. Nascimento T, Birnie DH, Healey JS, Verma A, Joza J, Bernier ML, Essebag V. Managing novel oral anticoagulants in patients with atrial fibrillation undergoing device surgery: Canadian survey. Can J Cardiol 2014; 30: 231-236.

33. Douketis JD. Perioperative management of patients who are receiving warfarin therapy: an evidence-based and practical approach. Blood 2011; 117: 5044-5049.

34. Pillarisetti JMR, Reddy S, Khalafi M, Raghav A, Sridhar M, Kanmanthareddy A, Atkins D, Reddy M, Lakkireddy D. Peri-procedural use of novel anticoagulation agents during cardiac device implantation. J Am Coll Cardiol 2014; 63 (12 Suppl): DOI: 10.1016/S0735-1097(14)60347-8.

35. Birnie DH, Healey JS, Wells GA, Verma A, Tang AS, Krahn AD, Simpson CS, Ayala-Paredes F, Coutu B, Leiria TL, Essebag V; BRUISE CONTROL Investigators. Pacemaker or defibrillator surgery without interruption of anticoagulation. N Engl J Med 2013; 368: 2084-2093. 
36. Birnie DH, Healey JS, Wells GA, Ayala-Paredes F, Coutu B, Sumner GL, Becker G, Verma A, Philippon F, Kalfon E, Eikelboom J, Sandhu RK, Nery PB, Lellouche N, Connoly SJ, Sapp J, Essebag V. Continued vs. interrupted direct oral anticoagulants at the time of device surgery, in patients with moderate to high risk of arterial thrombo-embolic events (BRUISE CONTROL-2). Eur Heart J 2018; 39: 3973-3979.

37. Mar PL, Familtsev D, Ezekowitz MD, Lakkireddy D, Gopinathannair R. Periprocedural management of anticoagulation in patients taking novel oral anticoagulants: Review of the literature and recommendations for specific populations and procedures. Int J Cardiol 2016; 202: 578-585.

38. Santangeli P, Di Biase L, Horton R, Burkhardt JD, Sanchez J, Al-Ahmad A, Hongo R, Beheiry S, Bai R, Mohanty P, Lewis WR, Natale A. Ablation of atrial fibrillation under therapeutic warfarin reduces periprocedura complications: evidence from a meta-analysis. Circ Arrhythm Electrophysiol 2012; 302-311.

39. Granger CB, Alexander JH, McMurray JJV, Lopes RD, Hylek EM, Hanna M, Al-Khalidi HR, Ansell J, Atar D, Avezum A, Bahit MC, Diaz R, Easton JD, Ezekowitz JA, Flaker G, Garcia D, Geraldes M, Gersh BJ, Golitsyn S, Goto S, Hermosillo AG, Hohnloser SH, Horowitz J, Mohan P, Jansky P, Lewis BS, Lopez-Sendon JL, Pais P, Parkhomenko A, Verheugt FW, Zhu J, Wallentin L; ARISTOTLE Committees and Investigators. Apixaban versus warfarin in patients with atrial fibrillation. N Engl J Med 2011; 365: 981-992.

40. Connolly SJ, Ezekowitz MD, Yusuf S, Eikelboom J, Oldgren J, Parekh A, Pogue J, Reilly PA, Themeles E, Varrone J, Wang S, Alings M, Xavier D, Zhu J, Diaz R, Lewis BS, Darius H, Diener HC, Joyner CD, Wallentin L; RE-LY Steering Committee and Investigators. Dabigatran versus warfarin in patients with atrial fibrillation. N Engl J Med 2009; 361: 1139-1151.

41. Giugliano RP, Ruff CT, Braunwald E, Murphy SA, Wiviott SD, Halperin JL, Waldo AL, Ezekowitz MD, Weitz JI, Špinar J, Ruzyllo W, Ruda M, Koretsune Y, Betcher J, Shi M, Grip LT, Patel SP, Patel I, Hanyok JJ, Mercuri M, Antman EM; ENGAGE AF-TIMI 48 Investigators. Edoxaban versus warfarin in patients with atrial fibrillation. N Engl J Med 2013; 369: 2093-2104.

42. Patel MR, Mahaffey KW, Garg J, Pan G, Singer DE, Hacke W, Breithardt G, Halperin JL, Hankey GJ, Piccini JP, Becker RC, Nessel CC, Paolini JF, Berkowitz SD, Fox KA, Califf RM; ROCKET AF Investigators. Rivaroxaban versus warfarin in nonvalvular atrial fibrillation. $\mathrm{N}$ Engl J Med 2011; 365: 883-891.

43. Krishnamoorthy A, Ortel T. A bridge to nowhere? Benefits and risks for periprocedural anticoagulation in atrial fibrillation. Curr Cardiol Rep 2016; 18: 101.

44. PERIOP 2 - A Safety and Effectiveness of LMWH vs Placebo Bridging Therapy for Patients on Long Term Warfarin Requiring Temporary Interruption of Warfarin. - Full Text View - ClinicalTrials.gov [Internet]. Available at: 29 May 2018. https://clinicaltrials.gov/ct2/show/NCT00432796.

45. Siegal DM, Curnutte JT, Connolly SJ, Lu G, Conley PB, Wiens BL, Mathur VS, Castillo J, Bronson MD, Leeds JM, Mar FA, Gold A, Crowther MA. Andexanet alfa for the reversal of factor Xa inhibitor activity. N Engl J Med 2015; 373: 2413-2424.

46. Pollack CV, Reilly PA, Eikelboom J, Glund S, Verhamme P, Bernstein RA, Dubiel R, Huisman MV, Hylek EM, Kam- phuisen PW, Kreuzer J, Levy JH, Sellke FW, Stangier J, Steiner T, Wang B, Kam CW, Weitz JI. Idarucizumab for Dabigatran Reversal. N Engl J Med 2015; 373: 511-520.

47. Douketis JD, Spyropoulos AC, Anderson JM, Arnold DM, Bates SM, Blostein M, Carrier M, Caprini JA, Clark NP, Coppens M, Dentali F, Duncan J, Gross PL, Kassis J, Kowalski S, Lee AY, Le Gal G, Le Templier G, Li N, MacKay E, Shah V, Shivakumar S, Solymoss S, Spencer FA, Syed S, Tafur AJ, Vanassche T, Thiele T, Wu C, Yeo E, Schulman S. The Perioperative Anticoagulant Use for Surgery Evaluation (PAUSE) study for patients on a direct oral anticoagulant who need an elective surgery or procedure: design and rationale. Thromb Haemost 2017; 117: 2415-2424.

48. Perioperative Anticoagulant Use for Surgery Evaluation Study - Full Text View - ClinicalTrials.gov [Internet]. Available at 29 May 2018. https://clinicaltrials.gov/ct2/ show/NCT02228798.

49. Nazha B, Pandya B, Cohen J, Zhang M, Lopes RD, Garcia DA, Sherwood MW, Spyropoulos AC. Periprocedural outcomes of direct oral anticoagulants vs. warfarin in non-valvular atrial fibrillation: a meta-analysis of phase III trials. Circulation 2018; 138: 1402-1411.

\section{Address for correspondence:}

\section{Agnieszka Łętek}

II Clinic of Cardiology

Regional Polyclinical Hospital

Kielce Region Centre of Cardiology

ul. Grunwaldzka 45, 25-736 Kielce, Poland

E-mail: agaletek@gmail.com 